\author{
Karolina Kocemba* \\ ORCID: 0000-0002-5621-0192
}

Uniwersytet Wrocławski, Centrum Edukacji Prawniczej i Teorii Społecznej

\author{
Michał Stambulski \\ ORCID: 0000-0003-4493-1272
}

Uniwersytet Zielonogórski, Uniwersytet Wrocławski, Centrum Edukacji Prawniczej i Teorii Społecznej

https://doi.org/10.19195/1733-5779.31.8

\title{
Populizm a polityka praw człowieka ${ }^{\star *}$
}

\section{JEL Classification: K38, K30, K39}

Słowa kluczowe: populizm, prawa człowieka, prawa LGBT, prawa kobiet, prawa migrantów, sprawiedliwość społeczna

Abstrakt: Artykuł zawiera rozważania na temat relacji dyskursu praw człowieka i populizmu. Autorzy najpierw przedstawiają przegląd stanowisk teoretycznych dotyczących populizmu, następnie określają pojęcie polityki praw człowieka. Prowadzi to do wniosku, że w celu zachowania swojego demokratycznego charakteru populizm musi akceptować, przynajmniej retorycznie, prawa człowieka. W następnej części autorzy przyglądają się działaniom wobec praw człowieka prowadzonym za czasów władzy populistycznej, na przykładzie rządów Prawa i Sprawiedliwości w latach 2015-2020. Uwzględniają przede wszystkim wypowiedzi polityków oraz działania wobec osób LGBT, praw reprodukcyjnych, praw imigrantów, a także prowadzone polityki socjalne. Analiza prowadzi do wniosku, że populiści prowadzą własną, odmienną od liberalnej, politykę praw człowieka. Populizm narusza prawa mniejszości, a wzmacnia prawa socjalne i dystrybuuje uznanie oparte na tożsamości narodowej. Wobec czego stosunek populizmu do praw człowieka nie jest jednoznaczny i nie polega na prostym odrzuceniu.

\section{Populism and the politics of human rights}

Abstract: The article reflects on the relationship between human rights discourse and populism. First, the authors present a review of theoretical positions regarding populism. Then they define the concept of human rights policy. This leads to the conclusion that populism must accept,

* Opiekun naukowy (Scientific Tutor) — Michał Paździora

** Niniejszy artykuł powstał w ramach grantu Narodowego Centrum Nauki, nr rej. 2015/17/N/ HS5/00733. 
at least rhetorically, human rights to preserve populism's democratic character. In the next part, the authors look at actions against human rights taken during populist regimes, via the example of the rule of Law and Justice (Prawo i Sprawiedliwość) in the years 2015-2020. They mainly take into account politicians' statements and actions against LGBT persons, reproductive rights, immigrant rights, as well as social policies. The analysis leads to the conclusion that populists pursue their own, different from liberal, politics of human rights. Populism violates minority rights and strengthens social rights and distributes recognition based on national identity. Therefore, populism's attitude to human rights is not explicit and does not consist of simple rejection.

Keywords: populism, human rights, LGBT rights, women's rights, immigrant rights, social justice

I od kiedy walka przeciw gwałceniu praw człowieka - która sama zaczyna się od jednostek, ale może być tylko kolektywna - z definicji tworzy część polityki praw człowieka, odkąd opór ten nigdy się nie kończy, mamy już pierwszy element odpowiedzi na nasze pytanie: polityka praw człowieka zawsze już się zaczęła, to jest zawsze już polityka praw człowieka.

Étienne Balibar

\section{Wstęp}

Powszechna narracja, jaką można znaleźć w artykułach prasowych oraz w wypowiedziach publicznych prawników, mówi, że populizm jest przeciwko prawom człowieka. Populiści, dążąc do nieograniczonej władzy, mają odrzucać jakiekolwiek jej ograniczenia prawne. Takim ograniczeniem mają być prawa człowieka. W rzeczywistości, jak to często bywa we współczesnym, powierzchownie postpolitycznym świecie społecznym, sytuacja jest bardziej skomplikowana. W artykule podejmujemy próbę opisu relacji populizmu i dyskursu praw człowieka z pozycji teoretycznospołecznej. Empiryczną podstawą rozważań jest Polska pod rządami Prawa i Sprawiedliwości w latach 2015-2020, w szczególności wypowiedzi polityków. Przyjętą perspektywą teoretyczną — współczesna krytyczna filozofia polityczna. Po przeglądzie stanowisk teoretycznych na kwestię populizmu, przyglądamy się, jakiego rodzaju naruszenia mają miejsce w czasach rządu populizmu, a jakie prawa są wzmacniane. W skrócie można powiedzieć, że populizm narusza prawa mniejszości, a wzmacnia prawa socjalne i dystrybuuje uznanie oparte na tożsamości narodowej. Całość rozważań prowadzi do wniosku, że populizm prowadzi własną, odmienną od liberalnej (ale wyrosłą na niej), politykę praw człowieka. 


\section{Czas populizmu}

Już w 2007 roku bułgarski politolog Ivan Krastev, na łamach czasopisma „Eurozine”, opublikował artykułu The populist moment, w którym stwierdził, że żyjemy w czasach populizmu1. Przekonać nas może już sama częstotliwość używania tego pojęcia w dyskursie publicznym. Jest to jedno z najczęściej używanych słów w opisie aktualnych wydarzeń politycznych. Nie jest to jednak pojęcie łatwe do zdefiniowania; ma wiele znaczeń, a jego zakres może być bardzo szeroki. Znacznie łatwiej wymienić cechy charakterystyczne dla tego fenomenu/ zjawiska. Przede wszystkim, jak podkreśla Anton Pelinka, populizm ściśle wiąże się ze społecznymi hierarchiami, to znaczy z relacjami między elitą a masami². Może dotyczyć wrogiego elitom nastawienia mas czy też wysiłków elit, które zmierzają do utrzymania poparcia udzielanego im przez „upośledzone masy”3. Może także oznaczać retorykę relatywnie nowych sił politycznych, które swoje aspiracje polityczne opierają na przeciwstawieniu wyalienowanych elit i ciężko pracujących mas. Z kolei Margaret Canovan, śledząc akademickie dysputy dotyczące definiowania populizmu, zauważyła, że oprócz opierania się na stosunku lud-elita populizm historycznie traktowano jako cechę społeczeństw wiejskich, które sprzeciwiają się modernizacji. W celu uporządkowania dyskusji Canovan proponuje rozróżnienie na perspektywę socjologiczną i polityczną ${ }^{4}$. Populizm w perspektywie socjologicznej jest uważany za ruch rolniczy, oparty na podłożu społeczno-gospodarczym, którym jest postępująca modernizacja i jej efekty — urbanizacja, otwarta wymiana handlowa, wzrost znaczenia przemysłu, sekularyzacja, migracje ludności itp. W Polsce charakter taki miała Samoobrona — partia polityczna istniejąca w latach 1992-2012, która krytykowała liberalną politykę ekonomiczną i postulowała pomoc państwa dla zadłużonych rolników. W perspektywie politycznej populizm wykracza poza ruch rolniczy i oznacza rodzinę zjawisk politycznych, w ramach których nawiązuje się do demokracji bezpośredniej, pobudza zaangażowanie emocjonalne mas, idealizuje przeciętnego człowieka czy jakikolwiek inny sposób „dochodzi do eskalacji napięć pomiędzy elitami a szarym obywatelem"s.

Tym, co jednak łączy oba rodzaje populizmu jest mechanizm ich powstania, którym są problemy społeczne czy gospodarcze. Te z kolei prowadzą do apeli i roszczeń do polityków, nawiązujących do ideologii demokratycznej — idei

${ }^{1}$ I. Krastev, The populist moment, https://www.eurozine.com/the-populist-moment/ (dostęp: 1.05.2020).

2 A. Pelinka, Populizm w Europie - w poszukiwaniu znaczenia mglistego pojęcia, [w:] Populizm w Europie. Defekt i przejaw demokracji?, red. J.M. De Waele, A. Pacześniak, Warszawa 2010, s. 18.

3 Ibidem.

${ }^{4}$ M. Canovan, Populizm, [w:] Populizm, red. O. Wysocka, Warszawa 2010, s. 56-64.

5 Ibidem, s. 59. 
suwerenności ludu i zasadzie większości ${ }^{6}$. Canovan mówi o populizmie jako efekcie „demokratycznego paradoksu”. Demokracja jako najbardziej inkluzywny system polityczny jest jednocześnie nieprzejrzysta. Przez ten roźdzwięk między ideą a praktyką demokracja ciągle potrzebuje ,przybliżania polityki ludziom”tworzenia prostych ram, tłumaczenia, kto jest za co odpowiedzialny lub (kto jest winny). Dzięki temu demokracja zachowuje swój potencjał krytyczny (możliwość zmiany władzy), lecz jest jednocześnie otwarta na manipulację. Populiści zdobywają poparcie dzięki wyrażaniu (i kształtowaniu) poglądów zwykłych ludzi, na podkreślaniu poglądów panujących wśród mas, które przez decydentów politycznych nie były rozpoznane lub były do tej pory zagłuszane ${ }^{7}$. Patrząc na podnoszone przez populistów kwestie (imigracja, zatrudnienie, wartości religijne), możemy domniemywać, że były one marginalizowane w sferze publicznej ze względu na polityczną poprawność, o którą populiści nie dbają. Z tego względu populizm bywa postrzegany jako zagrożenie, ale także jako korekta polityki będącej zbyt daleko od ludzi ${ }^{8}$.

To właśnie bliskość wobec ludu i pretensja do reprezentacji jego interesu wydaje się być rdzeniem populizmu. Wskazuje na to także Jan-Werner Müller, pisząc w swojej szeroko komentowanej książce Co to jest populizm?, że

populizm to szczególny rodzaj moralizującej wyobraźni politycznej i taki sposób postrzegania świata politycznego, który ustawia moralnie czysty i w pełni zjednoczony [...] naród czy lud naprzeciw elitom, ukazywanym jako skorumpowane bądź z innego powodu gorsze moralnie 9 .

Jest to więc mechanizm postrzegania świata politycznego w kategoriach moralnych. Jednocześnie jest to moralizm zero-jedynkowy - albo coś wyrasta $\mathrm{z}$ „dobrego" ludu, albo jest przeciwko niemu. Konsekwencją tego jest antypluralizm — populiści twierdzą, że to oni i tylko oni reprezentują naród ${ }^{10}$. Na podstawie tej definicji możemy stwierdzić także, że populiści dążą do społeczeństwa jednolitego, homogenicznego, w którym nie uwzględnia się odstępstw od normy ani mniejszości. Centralnym pojęciem populizmu jest niewątpliwie „lud”, z którym wiążą się także pojęcia demokracji, suwerenności i zasady większości, które definiuje się przez ich wzajemne więzi. Zdaniem Müllera populizm zawsze jest ,ludowy" - przynajmniej w pewnym stopniu ${ }^{11}$. Doprowadza to do sytuacji, w której demokrację sprowadza się do rządów suwerennego ludu, a nie elit — polityków, sędziów czy biurokratów ${ }^{12}$. Lud jest więc rozumiany jako najwyższy suweren,

${ }^{6}$ M. Canovan, Polityka dla ludzi. Populizm jako ideologia dla demokracji, [w:] Demokracja w obliczu populizmu, red. Y. Meny, Y. Surel, Warszawa 2007, s. 57-59.

7 Ibidem.

8 J.-W. Müller, Co to jest populizm?, przeł. M. Sutowski, Warszawa 2017, s. 24.

9 Ibidem, s. 40.

10 Ibidem, s. 17.

11 Ibidem, s. 39.

12 M. Canovan, Polityka dla ludzi..., s. 69. 
jako jedność, jako ciało mające wspólny interes i wspólną jedną wolę. Tego rodzaju podejście może stwarzać grunt pod ruchy nacjonalistyczne. Jak zauważa Seyla Benhabib:

„My, lud” to formuła rodząca napięcia i stworzona po to, by uniwersalizujące roszczenia praw oraz zakusy demokratycznej suwerenności dało się zawrzeć w granicach jakiejś zbiorowości usytuowanej w historycznym kontekście. Taka zbiorowość desygnuje jakichś „innych” — we własnym obrębie oraz „na zewnątrz”13.

Praktyka populizmu sprowadza się więc do definiowania ,ludu”. Z definiowaniem wiąże się władza wyznaczania granic tego, co jest definiowane — innymi słowy - definiowanie to kwestia polityczna par excellence. Definiowanie ludu i nazywanie jego oczekiwań mieści się w centrum demokracji. W tym sensie demokracja jest już zawsze populistyczna. Populizm sensu stricto pojawia się w momencie przekonania o wyłączności na reprezentację. Przekonanie takie, oparte na moralnej wyższości, prowadzi do odrzucenia liberalnych ograniczeń władzy i homogenizacji społecznej. Skoro populista jedynie ucieleśnia moralnie doskonały „lud”, to nie potrzebuje ograniczeń. Prawidłowość sprawowania władzy gwarantują nie procedury i ograniczenia, ale zasoby moralne. Moralną doskonałość najlepiej prezentować na tle jego przeciwieństwa - skorumpowania i zepsucia. W retoryce populizmu tę rolę odgrywają elity, które przedstawiane są jako pasożytujące na ciężkiej pracy i czystości ludu. Populizm projektuje swojego wroga-Innego, przeciwko któremu głosi potrzebę mobilizacji. Lud postrzegany jest jako jednolity i dlatego zakres Innego ma tendencję do rozszerzania się. Każdy, kto nie spełnia zdefiniowanych przez populizm kryteriów przynależności do „ludu”, jest Innym. Dlatego nowo skonstruowane ujednolicające definicje są często zestawiane z przymiotnikiem ,prawdziwy” — na przykład prawdziwy patriota, prawdziwy Polak, prawdziwa matka, prawdziwa kobieta, prawdziwa rodzina. Pojęcie ,prawdziwego" zakłada już w sobie sobowtóra-Innego, który tylku udaje (Polaka, matkę itp.).

Już na tym etapie rozważań możemy zauważyć, że założenia populistyczne nie współgrają z szerszą ideą praw człowieka: z różnorodnym społeczeństwem, z poszanowaniem praw ,innych”, z pluralizmem stylów życia w przestrzeni publicznej. Czy może bardziej precyzyjnie należałoby powiedzieć, że idea praw człowieka: oparta jest na innej wyobraźni politycznej i moralnej. Dyskurs praw człowieka opierał się na założeniach liberalizmu, to znaczy, przyjmując silne założenie o autonomii i racjonalności jednostki. Wobec tego szeroko rozumiane prawa człowieka są przeszkodą dla populizmu, kierującego się logiką wspólnoty-ludu i to przeszkodą istotną w homogenizacji społeczeństwa - wszelkie odstępstwa od normy, od wzoru nie są mile widziane.

Populizm jest ściśle związany z demokracją. W związku z tym, że w swoim centrum umieszcza ,prostego człowieka”, to nie może ignorować jego praw w swojej

13 S. Benhabib, Prawa innych. Przybysze, rezydenci i obywatele, przeł. M. Filipczuk, Warszawa 2015, s. 92. 
retoryce. W obronie tych praw przecież powstał. Umieszczając „lud” w centrum swojego dyskursu, ruch populistyczny musi umieścić tam także elementy tworzące „lud” - zwykłych ludzi, w imieniu których przemawia. Interes tych ludzi jest wyrażany w języku praw — ludzie „mają prawo do...”, ,zasługują na...” itp. Tego typu język nie tylko wyraża interes czy dążenie, ale także jest formą uznania. Twierdząc, że dany podmiot ma go czegoś prawo, wyrażamy jednocześnie, że podmiot ten jest godzien posiadania praw. Działa to także w drugą stronę. Populizm, który twierdziłby, że należy po prostu odrzucić prawa człowieka, popadłby w sprzeczność i stracił spójność normatywną. Taka postawa oznaczałaby uznanie, że co prawda lud jest moralnie wyróżniony, ale nie na tyle, by mieć prawa. Przy założeniu, że populizm u władzy nie odrzuca nigdy w pełni reguł demokratycznych, trwanie takiej niespójności mogłoby skutkować utratą władzy. To odróżnia populizm od władzy autorytarnej czy totalitarnej, które nie muszą się przejmować swoją spójnością. Wynika z tego, że populizm jest zmuszony w jakiś sposób wchodzić w interakcje z prawami człowieka, na przykład przez próby ich redefiniowania. To z kolei znaczyłoby, że populizm prowadzi swoją politykę praw człowieka.

\section{Polityka praw człowieka}

Drugim, oprócz populizmu, pojęciem, przydanym do analizy współczesnych procesów społeczno-prawnych, jest pojęcie polityki praw człowieka. Polityka? Prawa człowieka? Przecież one są apolityczne! — zanim pojawią się tego typu zastrzeżenia, pragniemy zwrócić uwagę, że wskazywanie na współzależność dyskursu praw człowieka od zjawisk politycznych jest już traktowane jako oczywiste $\mathrm{i}$ to nawet nie tyle przez przedstawicieli critical legal studies $^{14}$, ile także w naukowym mainstreamie ${ }^{15}$.

Historycznie prawa człowieka miały swoją politykę w tym sensie, że od końca lat siedemdziesiątych (prezydentura Jimmy’ego Cartera) były wykorzystywane jako argument delegitymizujący kraje realnego socjalizmu. Rozpad ZSRR oznaczał nie tylko bezalternatywność dla praw człowieka, lecz także dla kapitalizmu. Po 1989 roku wyobraźnia polityczna, zwłaszcza w krajach Europy Środkowo-Wschodniej, oraz sytuacja geopolityczna zostały oparte na przekonaniu o „końcu historii" "16. Procesy integracji europejskiej oraz działalność orzecznicza Europejskiego Trybunału Praw Człowieka sprawiły, że prawa człowieka stały się oczywistym komponentem systemów prawnych krajów europejskich. Sprawiło to, że polityczny aspekt często umyka naszej pozytywnoprawniczo zorientowanej świadomości. Dyskurs praw człowieka odnosi się do swojej polityczności niczym lis do pozostawianych na śniegu śladów — zamazuje je ogonem. Sprawia to, że umac-

${ }^{14}$ C. Douzinas, Human Rights and the Empire, Oxford-New York 2007.

15 Dobrym przykładem może być szeroko dyskutowana książka Samuela Moyna. Por. idem, The Last Utopia: Human Rights in History, Harvard 2012.

${ }^{16}$ F. Fukuyama, Koniec historii i ostatni człowiek, przeł. T. Bieroń, Kraków 2017. 
nia się przekonanie o uniwersalistycznych podstawach prawa człowieka i tym samym ich legitymizacja. W dłuższej perspektywie może to jednak prowadzić do osłabienia tych praw, do społecznej demobilizacji, kiedy prawa traktowane są jako oczywiste i niewymagające odpowiednich rozwiązań politycznych — jeśli prawa wyrastają z danej społeczności, to w celu ich zachowania niezbędne jest społeczne zaangażowanie.

Beth J. Singer, amerykańska teoretyczka prawa, zwraca uwagę na operatywność praw człowieka ${ }^{17}$. Singer słusznie podkreśla, że nie wystarczy formalne nadanie komuś praw przez państwo czy rząd, aby prawa te funkcjonowały. Prawa funkcjonują, jeśli są operatywne, to znaczy uznane przez członków danej wspólnoty. Jak stwierdza filozofka, ważne jest tu zachowanie nastawienia szacunku do praw:

W każdym społeczeństwie, w którym instytucja praw jest operatywna, istnieje generalne zobowiązanie do uznania i przestrzegania praw w każdym czasie, a nie tylko kiedy ktoś wzywa nas to jawnego wyrażenia takiego nastawienia. A wtedy, kiedy ktoś wzywa nas do zastosowania prawa, do wykonania zobowiązania, które oparte jest na danym prawie, to jakiekolwiek działanie wybierzemy, powinno ono wynikać z tego nastawienia. Powinniśmy działać ze względu na szacunek do praw-zobowiązań czy, jakby ujął to Kant, ze względu na ten szacunek i tylko we wzgląd na niego ${ }^{18}$.

Uznanie praw człowieka oparte jest na konstrukcji szacunku do praw, w ramach których jednostka, w momencie działania, nie tylko uznaje prawa za wiążące, ale uznaje także to, że każdy inny członek danej wspólnoty powinien je uznawać. W optyce Singera prawa są nie tyle nadawane, lecz wytwarzane w ramach „,wspólnoty normatywnej" (normative community). Wspólnoty różnią się między sobą, mając odmienne historie i kultury. Uznanie danych praw w jednej wspólnocie nie musi oznaczać uznania w innej. Tłumaczy to, dlaczego, pomimo globalnego dyskursu praw człowieka, zakres tych praw jest przedmiotem kontrowersji, a same prawa są nierównomiernie przestrzegane. Co jednak sprawia, że prawa są szanowane? Wydaje się, że gdy są zakorzenione kulturowo w danej wspólnocie. Innymi słowy szacunek do praw wymaga ich połączenia z symbolami i wartościami danej wspólnoty. Prawa zyskują tym samym oparcie w „świecie życia” danej społeczności, mają przełożenie na codzienne interakcje i relacje jednostek. Proces takiego zakorzenienia nie może być sprawą prostej inżynierii społecznej, lecz jest raczej organiczny, co nie znaczy, że nie można próbować nadać mu kierunku. Ważną rolę ogrywa tu edukacja.

Dostrzegając związek polityki i praw człowieka, francuski marksista Étienne Balibar stwierdził, że:

To, co nazywamy prawami demokratycznymi, stanowi zespół cywilnych wolności oraz indywidualnych i kolektywnych władz, których definicja była stopniowo rozwijana od początków powstania instytucji polityki (w Grecji i gdzie indziej), i które uniwersalistyczne „rewolucje” końca XVIII wieku ,ufundowały” dokładnie jako absolutne, „naturalne” pojęcie praw człowieka - to właśnie te demokratyczne prawa są, mniej lub bardziej, rozpoznawane i gwarantowane w podsta-

17 B.J. Singer, Pragmatism, Rights and Democracy, New York 1999.

18 Ibidem, s. 25. 
wowej konstrukcji nowoczesnych państw. Powiedzmy też, że podlegają one w czasie i przestrzeni znaczącym (i niebezpiecznym) fluktuacjom, to znaczy, że są one zdobywane, tracone i zdobywane na nowo w mniejszym lub większym zakresie ${ }^{19}$.

Do uznania praw niezbędna jest walka. W społeczeństwie autorytarnym ta walka przybiera postać walki o demokrację i wykracza poza porządek prawny — jest walką polityczną. Wynika to z tego, że w autorytarnym systemie prawnym nie ma gwarancji praw demokratycznych, które zapewniałyby realną możliwość zmiany władzy. W społeczeństwie demokratycznym taka walka jest jednocześnie polityczna i prawna. Istnieje tutaj realna możliwość wpływu na legislację, dlatego prawa człowieka proklamowano w deklaracji ,,praw człowieka i obywatela”. Element obywatelskości jest ściśle połączony z tymi prawami i wskazuje ich granice. Balibar zwraca naszą uwagę na to, że o ile proklamacja uniwersalności praw ma czasami uzasadnienie jako strategia polityczna, to uniwersalizm nie wyklucza historyczności. Prawa człowieka jako część politycznej kondycji zbiorowości ludzkich podlegają przemianom, w zależności od aktualnych relacji i konfliktów społecznych.

Patrząc na działania partii Prawo i Sprawiedliwość w Polsce w latach 20152020, możemy zaobserwować, z jednej strony, politykę ograniczania pewnych, uznanych wcześniej praw i odmowy przynależności do ludu, a z drugiej — politykę redystrybucji połączoną z uznaniem. Ograniczanie dotyczy zwłaszcza praw osób LGBT, praw reprodukcyjnych, czyli praw kobiet i imigrantów. Redystrybucja przybiera zaś formę programów socjalnych połączonych z dowartościowaniem kultury ludowej. Przyglądając się takiej polityce, będziemy chcieli ukazać nową logikę polityczną, która kieruje dystrybucją praw w populistycznej wspólnocie.

\section{Populizm a prawa mniejszości}

Przyjrzymy się teraz polityce praw człowieka w populizmie u władzy. Obserwując zarówno wypowiedzi medialne, jak i działania na poziomie legislacyjnym, możemy zauważyć, że populiści nie odnoszą się przychylnie do praw mniejszości seksualnych, praw reprodukcyjnych i praw imigrantów. Należy zacząć od wskazania, że choć ochrona tych praw przed przejęciem władzy przez populistów nie była na najwyższym poziomie, to jednak spełniała minimum standardu liberalno-europejskiego. Jak wskazuje Jeremy Waldron, w naszej publicznej moralności politycznej przeważa konstelacja, w której skład wchodzą rządy prawa, demokracja, wolny rynek i prawa człowieka ${ }^{20}$. Wszelkie odejście od tych wartości traktowane jest jako moralnie naganne i niepożądane - a zatem Polska, aspirując do bycia liberalną demokracją, a także krajem wchodzącym w skład wspólnoty europej-

19 É. Balibar, Co to jest polityka praw człowieka?, przeł. J. Kochan, http://www.nowakrytyka. $\mathrm{pl} / \mathrm{pl} /$ artykuly/Nk_on-line/?id=583 (dostęp: 24.05.2020).

20 J. Waldron, The rule of law and the importance of procedure, [w:] Getting to the Rule of Law, red. J.E. Fleming, New York 2011, s. 3. 
skiej, po 1989 roku musiała dostosować się do tego standardu. Wiązało się to z koniecznością ratyfikacji umów międzynarodowych dotyczących praw człowieka - na przykład aby uzyskać członkostwo w Radzie Europy, konieczne było ratyfikowanie Konwencji o ochronie praw człowieka i podstawowych wolności ${ }^{21}$. W tym samym okresie, w 1993 roku, Polska złożyła także deklarację o uznaniu jurysdykcji Europejskiego Trybunału Praw Człowieka.

W polskim prawie Konstytucja $\mathrm{RP}^{22}$ zakazuje dyskryminacji z jakiejkolwiek przyczyny w życiu politycznym, społecznym lub gospodarczym (art. 32), a kodeks pracy ${ }^{23}$ zakazuje dyskryminacji w zatrudnieniu (art. 183a). W procesie karnym osoby LGBT mogą odmówić zeznań dotyczących osoby najbliższej (art. 115 k.k.) ${ }^{24}$; jednocześnie nie ma możliwości zalegalizowania związku osób tej samej płci — Polska jest jednym z sześciu krajów w Unii Europejskiej, które nie uznają małżeństw homoseksualnych ani związków partnerskich ${ }^{25}$.

Partia rządząca jest wyraźnie przeciwna wprowadzeniu takich rozwiązań. Negatywnie wobec poszerzenia praw osób LGBT wypowiadał się lider partii PiS Jarosław Kaczyński. Odnosząc się do adopcji dzieci przez pary jednopłciowe, powiedział: „Tu mówimy nie, szczególnie jeśli chodzi o dzieci, wara od naszych dzieci”26. Wskazał także, że „później małżeństwa homoseksualne, a w końcu adopcja dzieci. Czyli dzieci jako przedmiot zabawy, przedmiot satysfakcji dla pewnych ludzi. Otóż nie. Nigdy nie. Dzieci są podmiotem, dzieci muszą być chronione, dzieci są wielkim skarbem, największym skarbem narodu" 27 . Z jego wypowiedzi można wywnioskować, że poszerzenie praw osób LGBT jest zagrożeniem dla dzieci. Niechęć populistów wobec związków partnerskich i małżeństw homoseksualnych, a także możliwości adopcji dzieci może wynikać z uznawania tylko jednego, właściwego, tradycyjnego modelu rodziny, który przez populistów jest propagowany. Osoby LGBT są z kolei traktowane jako realne zagrożenie dla ludu i dla wspólnoty, w których nie ma dla nich miejsca. Są przez populistów moralnie napiętnowane.

Wypowiedź przywódcy partii ma przełożenie na działania działaczy partyjnych na niższych szczeblach. Wyrazem działań przeciwko prawom osób LGBT

21 Europejska konwencja o ochronie praw człowieka i podstawowych wolności, https://www. gov.pl/web/rodzina/europejska-konwencja-o-ochronie-praw-czlowieka-i-podstawowych-wolnosci (dostęp: 4.05.2020).

22 Konstytucji Rzeczypospolitej Polskiej z dnia 2 kwietnia 1997 roku, Dz.U. z 1997 r. Nr 78, poz. 483.

23 Ustawa z dnia 26 czerwca 1974 roku - Kodeks pracy, Dz.U. z 1974 r. Nr 24, poz. 141.

24 Ustawa z dnia 6 czerwca 1997 roku — Kodeks karny, Dz.U. z 1997 r. Nr 88, poz. 553.

25 Oprócz Polski są to: Bułgaria, Łotwa, Litwa, Rumunia, Słowacja.

26 Jarosław Kaczyński: Wara od naszych dzieci, https://www.rp.pl/Prawo-i-Sprawiedliwosc/1903 19420-Jaroslaw-Kaczynski-Wara-od-naszych-dzieci.html (dostęp: 1.05.2020).

27 Prezes PiS: „Nie będzie w Polsce matżeństw homoseksualnych, nie będzie adopcji dzieci”. Plan Rabieja? „Nie, nigdy nie”, https://wpolityce.pl/polityka/463846-prezes-pis-trwa-atak-na-dzieci-my-sie-na-to-nie-zgadzamy (dostęp: 1.05.2020). 
jest tworzenie tak zwanych stref wolnych od LGBT", czyli podejmowanie przez samorządy uchwał „przeciwko ideologii LGBT”. Warto podkreślić, że PiS wygrało wybory samorządowe w 2018 roku. Populistyczna partia uzyskała także znaczącą przewagę w radach gmin ${ }^{28}$. Uchwały były przedstawiane jako reakcja na podpisanie przez prezydenta Warszawy deklaracji popierającej poszanowanie praw osób LGBT, a także zapowiedź włączenia tematyki LGBT do programów edukacji seksualnej w warszawskich szkołach ${ }^{29}$. Możemy jednak uznać, że był to jedynie pretekst, gdyż strefy wolne od LGBT wpisują się w szerszą wizję sfery i przestrzeni publicznej propagowaną przez partię, w której nie ma miejsca na LGBT. Podjęte uchwały nie mają mocy prawnej, jednak wyrażają stosunek samorządowców z danego regionu wobec osób LGBT. W uchwałach pojawiały się zapisy o wyrażeniu sprzeciwu wobec ideologii LGBT w sferze publicznej ${ }^{30}$, edukacji seksualnej według WHO, kontroli poprawności politycznej w szkołach, a także wierność tradycji narodowej i państwowej ${ }^{31}$. Co ciekawe, takimi strefami objęto aż 30\% obszaru kraju, przede wszystkim południowo-wschodnią część Polski ${ }^{32}$. Jednak akcja powoduje kolejne - ustanowienie tych stref zachęciło do drukowania naklejek „strefa wolna od LGBT” w prorządowej „Gazecie Polskiej”33.

Sprzeciw wobec osób LGBT w sferze publicznej może wpływać także na większą nietolerancję w codziennych interakcjach. Przykładem tego jest sprawa dru-

28 Państwowa Komisja Wyborcza, https://wybory2018.pkw.gov.pl/pl/dane-w-arkuszach (dostęp: 24.05.2020).

29 Kaczyński: homoseksualiści kwestionujący rodzinę zagrożeniem dla cywilizacji, https:// queer.pl/news/203956/kaczynski-homoseksualisci-kwestionujacy-rodzine-zagrozeniem-dla-cywilizacji (dostęp: 1.05.2020).

30 Straszenie przez populistów ,ideologią LGBT” jest pokłosiem, a nawet przeobrażeniem straszenia ,gender”, które dokładnie opisał Maciej Duda w książce Dogmat Płci. Polska wojna z gender. Zauważył on, że przez komentujących pojęcia, takie jak ,ideologia gender”, „związki partnerskie”, „,in vitro”, „polityka równościowa” zostały ze sobą zrównane i były rozumiane jako popularyzacja związków jednopłciowych, a czasami nawet jako seksualizacja i pedofilia. Zarówno „ideologia gender”, jak i ,ideologia LGBT” są pojęciami, które były wykorzystywane przez populistów niczym naczynia, do których wrzucali wszelkie niepasujące im ze względów aksjologicznych działania i zjawiska, etykietując je jako pedofilia czy seksualizacja - pojęciami budzącymi niewątpliwie negatywne skojarzenia, wszakże pedofilia jest przestępstwem. Mało tego, straszak działał najlepiej, kiedy mówiono, że potwór gender czy LGBT zaatakuje ich dzieci. Zob. M. Duda, Dogmat płci. Polska wojna z gender, Gdańsk 2016, s. 86.

${ }^{31}$ K. Kubicka-Żach, Uchwaty anty-LGBT przyjmowane raczej ,,na wyrost”, https://www.prawo.pl/ samorzad/uchwaly-anty-lgbt-powody-ich-przyjmowania-przez-rady,456469.html (dostęp: 1.05.2020).

32 M. Ciastoch, 30 proc. Polski to strefy, wolne od LGBT". Ta mapa pokazuje, gdzie zezwala się na nienawiść, https://noizz.pl/lgbt/mapa-nienawisci-wobec-lgbt-30-proc-polski-to-strefy-wolne-od-lgbt-atlas-nienawisci/r3erj5p (dostęp: 1.05.2020).

33 , Gazeta Polska” z nalepka ,, Strefa wolna od LGBT". Rabiej zglosi to do prokuratury, Sakiewicz zarzuca mu cenzure, https://www.wirtualnemedia.pl/artykul/gazeta-polska-strefa-wolna-od-lgbt-naklejka-pawel-rabiej-zglosi-to-do-prokuratury-tomasz-sakiewicz-zarzuca-mu-cenzure\# (dostęp: 24.05.2020). 
karza z Łodzi, którzy odmówił wydrukowania plakatu organizacji LGBT. Sprawa jest o tyle wyjątkowa, że kilkukrotnie ingerował w nią prokurator generalny, będący jednocześnie ministrem sprawiedliwości. Zarówno sąd pierwszej ${ }^{34}$, jak i drugiej instancji ${ }^{35}$ uznał drukarza za winnego wykroczenia. Wobec tego Prokurator Generalny złożył kasację od wyroku sądu drugiej instancji. Kiedy Sąd Najwyższy stwierdził, że rzemieślnik nie może powoływać się na klauzulę sumienia i nie mógł odmówić wydruku ${ }^{36}$, Prokurator Generalny zaskarżył do Trybunału Konstytucyjnego przepis kodeksu wykroczen ${ }^{37}$, na podstawie którego drukarz został uznany za winnego. Trybunał Konstytucyjny, w którym większość składu sędziowskiego została powołana przez partię rządzącą, stwierdził z kolei, że przepis ten jest niekonstytucyjny, gdyż ingeruje „,W wolność podmiotu świadczącego usługi, w szczególności w prawo do decydowania o zawarciu umowy, prawa do wyrażania własnych opinii czy postępowania zgodnie z własnym sumieniem"38. Trybunał Konstytucyjny w niniejszym orzeczeniu uznał, że wolność sumienia jest ważniejsza niż ochrona przed dyskryminacją. Ten wyrok, a także pozostałe działania populistycznej partii rządzącej, wyraźnie zmierzają ku wyeliminowaniu widoczności osób LGBT w sferze i przestrzeni publicznej, co doprowadziłoby do traktowania osób LGBT tak jak w PRL — tak, jakby ich nie było.

Warto jednak wskazać, że próba wykluczenia osób LGBT ze sfery publicznej ma daleko idące skutki. Oprócz ataków fizycznych na uczestników marszów równości, dochodzi do ataków słownych na osoby LGBT — geje znajdują się w czołówce obrażanych mniejszości ${ }^{39}$. Znajduje to odzwierciedlenie w europejskim rankingu ILGA Europe, który bierze pod uwagę takie kwestie, jak: równość, kwestie rodzinne, mowa nienawiści, legalność zmiany płci, wolność słowa i prawa do azylu ${ }^{40}$. Polska w tym rankingu w 2020 roku zajęła ostatnie miejsce (dwudzieste siódme) w Unii Europejskiej, natomiast w latach 2017-2019 była trzykrotnie na miejscu przedostatnim ${ }^{41}$. Pozycja $\mathrm{w}$ rankingu zaczęła się pogarszać od 2015 roku, czyli kiedy PiS doszło do władzy — jeszcze w 2013 roku Polska była na miejscu dwudziestym trzecim. Przedtem istniała tendencja wzrostowa, co świadczy o lepszej

34 Wyrok Sądu Okręgowego w Łodzi z dnia 26 maja 2017 roku, sygn. akt. V Ka 557/17.

35 Wyrok Sądu Rejonowego dla Łodzi-Widzewa w Łodzi z dnia 31 marca 2017 roku, sygn. akt. VII W 1640/16.

36 Wyrok Sądu Najwyższego z dnia 14 czerwca 2018 roku, sygn. akt. II KK 333/18.

37 Ustawa z dnia 20 maja 1971 roku - Kodeks wykroczeń: „Kto, zajmując się zawodowo świadczeniem usług, żąda i pobiera za świadczenie zapłatę wyższą od obowiązującej albo umyślnie bez uzasadnionej przyczyny odmawia świadczenia, do którego jest obowiązany, podlega karze grzywny", tekst jedn. Dz.U. z 2019 r. poz. 821, art. 138.

38 Wyrok Trybunału Konstytucyjnego z dnia 26 czerwca 2019 roku, sygn. akt. K 16/17.

39 M. Bilewicz et al., Mowa nienawiści, mowa pogardy w Polsce 2016, https://www.batory.org.pl/ upload/files/pdf/MOWA_NIENAWISCI_MOWA_POGARDY_INTERNET.pdf (dostęp: 1.05.2020).

40 Ibidem.

41 Ibidem. 
ochronie prawnej ${ }^{42}$. Patrząc na działania PiS w sprawie praw osób LGBT, możemy zauważyć, że działania legislacyjne nie były podejmowane, natomiast faktyczne ograniczanie dostępu do praw następowało poprzez interpretację przepisów oraz wytwarzanie atmosfery wrogości poprzez symboliczną stygmatyzację.

Dużym zainteresowaniem populistów cieszą się także prawa reprodukcyjne. W tej sferze, znacznie częściej niż wobec osób LGBT, politycy partii podejmowali lub próbowali podejmować działania legislacyjne, zwłaszcza ze względu na nacisk środowisk katolickich ${ }^{43}$. Ustawa z dnia 27 kwietnia 1956 roku o warunkach dopuszczalności przerywania ciąży przewidywała możliwość wykonania aborcji ze względu na trudne warunki życiowe kobiety ciężarnej ${ }^{44}$. Na temat praw reprodukcyjnych zaczęto debatować już w 1989 roku. Wówczas grupa posłów z Polskiego Związku Katolicko-Społecznego złożyła w Sejmie projekt ustawy o ochronie życia poczętego, który był przygotowany przede wszystkim przez ekspertów z episkopatu. W związku z tym odbywały się protesty przeciwko zaostrzeniu dostępu do aborcji. Mimo to ograniczenie aborcji nastąpiło w 1993 roku za sprawą ustawy o planowaniu rodziny, czyli tak zwanego kompromisu aborcyjnego - uchwalono ustawę dopuszczającą aborcję w trzech przypadkach (gwałt, zagrożenie życia/ zdrowia kobiety, uszkodzenie płodu) ${ }^{45}$. W 1996 roku, po zmianie rządu, dodano przesłankę aborcji ze względów społecznych. Została ona uchylona słynnym orzeczeniem Trybunału Konstytucyjnego w 1997 roku $^{46}$. Taka dopuszczalność aborcji (w trzech przypadkach) obowiązuje do tej pory. Należy jednak wskazać, że jest to wyjątek na tle Unii Europejskiej — bardziej restrykcyjnie jest jedynie na Malcie, gdzie aborcja jest całkowicie zakazana ${ }^{47}$.

Warto podkreślić, że stanowiska dotyczące aborcji są wśród populistów podzielone — przykładowo Jarosław Kaczyński wskazywał, że nie poparłby projektu całkowicie zakazującego aborcji, gdyż jego zdaniem państwo pewniej granicy przekraczać nie powinno $^{48}$. Nietrudno natomiast znaleźć posłów i posłanki PiS, którzy aborcji zakazaliby całkowicie. Od czasu dojścia do władzy populistów próbowano zaostrzyć możliwość wykonywania aborcji. W październiku 2016 roku do Sejmu trafił projekt „Stop aborcji”, całkowicie zakazujący usuwania ciąży. Reakcją kobiet na próbę zaostrzenia

42 Rainbow Europe 2013, https://www.ilga-europe.org/rainboweurope/2013 (dostęp: 15.05.2020).

43 K. Kocemba, Kontrpubliczności polskiego konstytucjonalizmu na przykładzie praw kobiet, „Krytyka Prawa” 11, 2019, nr 1, s. 70-71.

44 Ibidem.

45 Ibidem.

46 Orzeczenie Trybunału Konstytucyjnego z dnia 28 maja 1997 roku, sygn. akt. K 26/96.

47 Federacja na Rzecz Kobiet i Planowania Rodziny, Prawa reprodukcyjne kobiet. Wybrane ustugi zdrowia reprodukcyjnego w krajach Unii Europejskiej, https://rownosc.info/media/uploads/ zdrowie_reprodukcyjne_ue.pdf (dostęp: 1.05.2020).

48 Kaczyński: Będziemy dążyli do tego, aby aborcji było dużo mniej niż obecnie, https://www. $\mathrm{mp} . \mathrm{pl} /$ pacjent/ciaza/aktualnosci/151453,kaczynski-bedziemy-dazyli-do-tego-aby-aborcji-bylo-duzo-mniej-niz-obecnie (dostęp: 1.05.2020). 
ustawy aborcyjnej były tak zwane czarne protesty, które organizowane były niemalże we wszystkich miastach $w$ Polsce ${ }^{49}$. $Z$ dużą dozą prawdopodobieństwa możemy przyznać, że dzięki nim projekt został odrzucony w Sejmie po pierwszym czytaniu. Kobiety wyszły na ulicę kolejny raz w marcu 2018 roku, co było spowodowane posiedzeniem komisji, która pozytywnie zaopiniowała projekt zabraniający przerywania ciąży ze względu na ciężkie wady płodu. Ta próba także się nie powiodła. PiS miało zasadę polegającą na nieodrzucaniu projektów obywatelskich w pierwszym czytaniu, co miało być przejawem ,szacunku dla demokracji”. Niemniej jednak posłowie nie skierowali do dalszych prac projektu „Ratujmy Kobiety” liberalizującego aborcję — został on odrzucony w pierwszym czytaniu, mimo że była to inicjatywa obywatelska $^{50}$. Każda próba zaostrzenia aborcji kończyła się protestami, co nie znaczy, że politycy partii zrezygnowali z prób ograniczenia praw reprodukcyjnych — tak jak w przypadku praw osób LGBT skorzystano z instytucji Trybunału Konstytucyjnego. Prokurator generalny Zbigniew Ziobro, jak i wielu innych posłów PiS uznał za niezgodną z Konstytucją przesłankę dokonania aborcji ze względu na ciężkie wady pło$\mathrm{du}^{51}$, w związku z czym złożono wniosek do Trybunału Konstytucyjnego o stwierdzenie niezgodności z Konstytucją przesłanki dokonywania aborcji ze względu na wady płodu. Należy wskazać, że w 2017 roku zdecydowana większość (98\%) aborcji była dokonywana właśnie ze względu na wady płodu ${ }^{52}$. Trybunał jeszcze nie rozstrzygnął tej sprawy, natomiast w przypadku uznania tej przesłanki za niezgodną z Konstytucją, legalna aborcja w Polsce w praktyce zostałaby niemalże wyeliminowana.

Kolejnym działaniem ograniczającym prawa reprodukcyjne było ustawowe wprowadzenie antykoncepcji awaryjnej tylko na receptę. Ówczesny minister zdrowia Konstanty Radziwiłł, zaostrzając dostęp do tak zwanej tabletki „dzień po”, argumentował decyzję nadużywaniem tych środków przez nastolatki ${ }^{53}$, mimo że badania wskazywały, że osoby niepełnoletnie, które korzystały z antykoncepcji awaryjnej, stanowiły jedynie $2 \%$. Warto podkreślić, że ustawa weszła w życie, gdy lekarze mogli powoływać się już na tak zwaną klauzulę sumienia. Sam minister stwierdził, że jako lekarz nie przepisałby pacjentce takiej antykoncepcji, nawet gdyby została zgwałcona - powołałby się na klauzulę sumienia ${ }^{54}$. Dostęp

49 K. Kocemba, op. cit.

50 D. Flis, PiS złamał obietnice wyborczą. Odrzucajac projekt „, Ratujmy Kobiety”, https://oko. press/pis-zlamal-obietnice-wyborcza-odrzucajac-projekt-ratujmy-kobiety/ (dostęp: 1.05.2020).

51 Zbigniew Ziobro: aborcja niezgodna z Konstytucja, https://www.rp.pl/Zdrowie/305299968-Zbigniew-Ziobro-aborcja-niezgodna-z-Konstytucja.html (dostęp: 1.05.2020).

52 Dane o legalnej aborcji 2017 roku, https://federa.org.pl/dane2017/ (dostęp: 1.05.2020).

53 M. Chrzczonowicz, Nastolatki opychaja się pigułkami dzień po. Sa badania, które dementuja bzdure Radziwiłta, https://oko.press/nastolatki-opychaja-sie-pigulkami-dzien-sa-badania-ktore-dementuja-bzdure-radziwilla/ (dostęp: 1.05.2020).

${ }^{54}$ M. Kraus, Radziwitt powiedzial, że nie przepisatby pigulki ,,dzień po" nawet pacjentce zgwatconej. ,Taka odmowa jest bezprawna”, https:/www.wysokieobcasy.pl/wysokie-obcasy/7,115167,214 10876,radziwill-powiedzial-ze-nie-przepisalby-pigulki-dzien-po-nawet.html (dostęp: 1.05.2020). 
do antykoncepcji awaryjnej został więc uzależniony od akceptacji przez lekarza, który może dokonywać nie tylko oceny medycznej, ale także moralnej. Dostęp do realizacji prawa zostaje uzależniony od osądu moralnego lekarza. Ochrona integralności moralnej lekarza zostaje tym samym uznana za ważniejszą niż kobiece prawo do antykoncepcji.

Tematem, na który PiS wypowiadał się bardzo często w mediach, są kwestie związane z kryzysem migracyjnym w 2015 roku i prawami imigrantów. W tym przypadku jest bardzo łatwo o wprowadzenie dychotomii „my”-,,oni”, opartej na podziale narodowościowym. Wzmacnianie tego podziału sprzyja budowaniu społecznej tożsamości - więzi wzmacniane są w obrębie własnej grupy i polegają na przypisywaniu „nam” cech pozytywnych, natomiast „im” — obcym, innym - cech negatywnych ${ }^{55}$. Oznacza to, że „ich” nie traktuje się jako części wspólnoty. Straszenie imigrantami i pokazanie wyraźnej niechęci było elementem kampanii wyborczej. Mogło się natomiast przyczynić do znacznego wzrostu mowy nienawiści, a także zwiększenia liczby ataków na tle rasistowskim. Jak wskazują autorzy raportu dotyczącego mowy nienawiści, wiele napaści, o których można było przeczytać w mediach w 2016 roku, łączy niewątpliwie tło rasistowskie. Niemalże w każdym wypadku napaść poprzedzały obraźliwe słowa dotyczące wyznawców islamu, Ukraińców czy też osób czarnoskórych ${ }^{56}$. Brutalizacja języka w sferze publicznej wpłynęła wówczas na brutalizację języka i zachowań w przestrzeni publicznej — jak już wcześniej wskazywano, populiści nie zważają na poprawność polityczną, a wyrażają poglądy panujące wśród ludu. W kampanii wyborczej wykorzystane zostały negatywne emocje, które do tej pory były zagłuszane. Aktywny był przede wszystkim Jarosław Kaczyński, którego wypowiedzi były wielokrotnie komentowane. Sprzeciw wobec przyjmowania uchodźców był bardzo wyraźny - Kaczyński wskazywał, że mamy „pełne moralne prawo” nie przyjmować uchodźców ${ }^{57}$. Niemniej jednak oprócz sprzeciwu wypowiedzi te były nacechowane dużą niechęcią, a także mogły wywołać uczucie strachu i obawy o bezpieczeństwo; Kaczyński stwierdził, że uchodźcy przenoszą choroby ${ }^{58}$ i przyczyniają się do zmniejszenia bezpieczeństwa, w tym do terroryzmu ${ }^{59}$.

55 C.N. Macrae, Ch. Stangor, M. Hewstone, Stereotypy i uprzedzenia, przeł. M. Majchrzak, A. i M. Kacmajor, A. Nowak, Gdańsk 1999, s. 53.

${ }^{56}$ M. Bilewicz, op. cit.

57 J. Kaczyński o imigrantach: Mamy petne moralne prawo powiedzieć „,nie”, https://niezalezna.pl/101460-j-kaczynski-o-imigrantach-mamy-pelne-moralne-prawo-powiedziec-nie (dostęp: 1.05.2020).

58 P. Pacewicz, „Tu chodzi o zwykłe, codzienne bezpieczeństwo Polaków”. Kaczyński mówi o ,uchodźcach”, ale narusza bezpieczeństwo ,obcych”, którzy już w Polsce sa, https://oko.press/ chodzi-o-zwykle-codzienne-bezpieczenstwo-polakow-kaczynski-mowi-o-uchodzcach-narusza-bezpieczenstwo-obcych-ktorzy-juz-polsce-sa/ (dostęp: 1.05.2020).

59 Ibidem. 
Należy jednak wskazać, że mimo niechęci wobec przyjmowania imigrantów to właśnie za czasów rządów Zjednoczonej Prawicy w Polsce odnotowano rekordową liczbę imigrantów. Wyniki raportu Eurostatu wskazują, że Polska w 2017 roku wydała sześćset osiemdziesiąt trzy tysiące dokumentów pobytowych dla obywateli spoza Unii Europejskiej - najwięcej spośród krajów Unii Europejskiej. Jednak prawie $86 \%$ to Ukraińcy, następnie Białorusini, a następnie Rosjanie. W tej grupie znajdują się także Syryjczycy, Irakijczycy i obywatele Bangladeszu ${ }^{60}$. W większości są to imigranci zarobkowi, jednak pod względem przyjęć w ostatnich latach, mimo zaostrzonej retoryki, Polska nie wyróżniała się na tle innych krajów europejskich. Warto natomiast zwrócić uwagę na pewnego rodzaju selekcję - mimo że przyjmowani imigranci nie są traktowani jako część wspólnoty, to nie są tak bardzo „Inni” — nie wyróżniają się na ulicy, ich kultura, język i obyczaje są podobne.

Na tych przykładach możemy zauważyć, że negatywny stosunek populistów do praw człowieka jest widoczny przede wszystkim w retoryce publicznej, a rzadziej w działaniach legislacyjnych. Populizm, przez opartą na moralności definicję „prawdziwego” członka wspólnoty, wyklucza ze sfery publicznej osoby, które ze względu na orientację, styl życia, pochodzenie kulturowe nie odpowiadają takiej definicji. Przytoczone przykłady wskazują, że władza populistyczna, ze względu na chęć zachowania fasady - czyli dostosowania się do standardu europejskiego, nie atakuje praw bezpośrednio, ale prowadzi swoją politykę przez narzucenie własnej interpretacji przepisów (na przykład przy pomocy TK), przez akty i działania o charakterze symbolicznym oraz przez rzeczywiste utrudnianie dostępu — uzależnienie możliwości korzystania z praw do oceny moralnej. W wypadku rządów autorytarnych mamy do czynienia $z$ bezpośrednim ograniczaniem praw przez legislację, natomiast w wypadku rządów populistycznych istnieje próba zachowania pozorów poprzez miękkie działania. Widzimy także, że działania te są rozproszone - w ograniczaniu praw bierze wiele podmiotów — rząd, samorządowcy, Trybunał Konstytucyjny, media.

Obserwując działania populistów, możemy być pewni, że nie dojdzie do poszerzenia tych praw - populiści nie wprowadzą związków partnerskich, a tym bardziej małżeństw homoseksualnych, nie zliberalizują prawa aborcyjnego ani nie będą witali uchodźców z Bliskiego Wschodu.

\section{Populizm a prawa socjalne}

Po dojściu do władzy Prawo i Sprawiedliwość wprowadziło kilka programów socjalnych, które wskazują na zerwanie z wcześniejszą narracją, jakoby programy socjalne były niemożliwe w Polsce z powodu niezamożności polskiego społeczeń-

${ }^{60}$ B. Rumieńczyk, Temat, który rozpalit nas do czerwoności. I o którym zapomnieliśmy, https:// wiadomosci.onet.pl/tylko-w-onecie/polityka-pis-wobec-imigrantow/elxnpq0 (dostęp: 1.05.2020). 
stwa i powiązanych z tym niskich wpływów budżetowych oraz niemożności ich finansowania $\mathrm{z}$ budżetu państwa.

Flagowym projektem PiS i rządu Zjednoczonej Prawicy jest program Rodzina $500+$. Jest to świadczenie rodzinne wprowadzone w 2016 roku w kwocie 500 złotych miesięcznie, mające pomóc rodzicom w wychowaniu dzieci. Od 1 lipca 2019 roku świadczenie to przysługuje na każde dziecko, niezależnie od dochodów rodziców. Program ten przez polityków obozu rządzącego przedstawiany jest jednocześnie jako narzędzie polityki socjalnej i element polityki przywracania obywatelom godności. W zakresie socjalnym, jak możemy przeczytać na stronie Ministerstwa Rodziny i Polityki Społecznej, program ten realizuje przede wszystkim trzy cele: „wpływa na wzrost liczby urodzeń (współczynnik dzietności wzrósł z 1,29 w 2015 roku do 1,45 w 2017 roku), ogranicza ubóstwo, w szczególności wśród dzieci (w latach 2015-2017 ubóstwo skrajne spadło z 6,5 do 4,3 proc.) oraz stanowi inwestycję w rodzinę"61. W aspekcie godnościowym program ten ma przywracać godność poprzez uznanie założenia rodziny jako działania docenianego przez państwo. Widoczne jest to w tej wypowiedzi Jarosława Kaczyńskiego:

Atakują naszą politykę społeczną, mówiąc, że to rozdawnictwo. Nie rozumieją, jakie są wielkie cele tej reformy. Ubóstwo poniża, odbiera wolność, to zjawisko zdołaliśmy ograniczyć. Nasi przeciwnicy atakują naszą politykę społeczną, co gorsza atakują polskie rodziny i dzieci. Przywrócenie godności Polaków jest naszym wielkim celem, nasi przeciwnicy tego celu nie rozumieją ${ }^{62}$.

Program ten jest więc przedstawiany jako „przywrócenie godności” rodzinie, której wcześniejsze liberalne rządy nie dostrzegały i nie szanowały. W podobnym tonie wypowiedziała się była minister rdziny, pracy i polityki społecznej Bożena Borys-Szopa, która stwierdziła, że ,rodzina jest naszym priorytetem i najlepszą inwestycją"63. Potwierdzeniem tego jest też wypowiedź byłej premier Beaty Szydło: ,przepychanki polityczne, które serwuje Polakom koalicja rządząca PO-PSL i zajmowanie się wyłącznie własnymi sprawami, zupełnie odrealniło polityków. Nie potrafią się na przykład spotkać z rodzinami i rozmawiać o problemach"64. „Dzieci” i „rodzina” pojawiają się bardzo często w wypowiedziach polityków PiS i to do tej grupy kierowanych jest najwięcej programów socjalnych. Pojęcie „rodzin” ma jednak charakter normatywny. Warto podkreślić, że jedynie „prawdziwa rodzina” jest tutaj chroniona - pierwotnie program 500+ nie był kierowany na pierwsze

61 Rodzina 500 plus, https://www.gov.pl/web/rodzina/rodzina-500-plus (dostęp: 1.05.2020).

${ }^{62}$ Kaczyński: naszym wielkim celem jest przywrócenie godności Polaków!, https://telewizjarepublika.pl/kaczynski-naszym-wielkim-celem-jest-przywrocenie-godnosci-polakow,77247.html (dostęp: 1.05.2020).

${ }^{63}$ Min. B. Borys-Szopa: Rodzina jest naszym priorytetem i najlepsza inwestycja, https://www. radiomaryja.pl/informacje/min-b-borys-szopa-rodzina-jest-naszym-priorytetem-i-najlepsza-inwestycja/ (dostęp: 1.05.2020).

${ }^{64}$ Szydło: 500 złotych na drugie dziecko będzie moim pierwszym projektem, http://web.archive.org/web/20150904142630/https://www.tvn24.pl/wiadomosci-z-kraju,3/500-zlotych-na-drugie-dziecko-pierwszym-projektem-beaty-szydlo,573711.html (dostęp: 1.05.2020). 
dziecko, tylko dopiero na drugie i kolejne. Krytycy często przywoływali przykład samotnej matki, która takiego świadczenia by nie dostała, natomiast osoby, które stać na utrzymanie dzieci, ale mają ich więcej niż jedno, już tak ${ }^{65}$.

Elementem takiej polityki socjalnej jest także program „Dobry start”, wprowadzony w 2018 roku. Program ten, zwany potocznie „,300 plus”, jest wypłacany w formie wyprawki szkolnej i ma za zadanie wesprzeć dzieci szkolne. Program ten ma być powiązany z innymi programami, takimi jak darmowe podręczniki. Przedstawiając „Dobry start”, premier Mateusz Morawiecki stwierdził, że jest to „,bardzo istotny program wspierający rodziny, ponieważ stanowi kolejny element wzmocnienia polityki prorodzinnej obecnego rządu” oraz że ,z rozmów z Polakami, które teraz odbywamy w wielu miejscach kraju, przebija ogromna radość i zadowolenie, że rząd PiS-u w taki sposób gospodaruje finansami publicznymi państwa" ${ }^{\prime 66}$.

Kolejnym wsparciem dla „prawdziwych rodzin” było wprowadzenie ograniczeń w handlu w niedzielę — była premier stwierdziła, że niedziela jest dla rodziny i wszyscy pracownicy powinni mieć przywilej spędzania jej z rodziną ${ }^{67}$. W tej sprawie PiS działało w zgodności z Episkopatem Kościoła katolickiego, który popierał całkowity zakaz handlu w niedzielę: „Niedziela może znów stać się gwarantem emocjonalnego wyciszenia, a także budowania wspólnoty rodzinnej, religijnej i narodowej" ${ }^{68}$. Chodziło więc o narzucenie jedynego właściwego spędzania czasu w niedzielę. Pomysłodawcy tego projektu pisali wprost: „niedziela dla katolików to dzień Pański, poświęcony przede wszystkim Bogu, ale też sobie i bliźnim"69.

PiS zwróciło się także ku seniorom, wśród których ma bardzo wysokie poparcie ${ }^{70}$. Otrzymali oni tak zwaną trzynastą emeryturę, co było ogłoszone podczas kampanii wyborczej do parlamentu — Jarosław Kaczyński zapowiedział wówczas, że „bę-

65 Zandberg: Świadczenia społeczne, jak 500+, powinny być indeksowane, https://www.gazetaprawna.pl/artykuly/1207851,zandberg-swiadczenia-spoleczne-500-plus-powinny-byc-indeksowane.html (dostęp: 1.05.2020).

66 Premier Mateusz Morawiecki o korzyściach programu „Dobry Start” https://www.premier. gov.pl/wydarzenia/aktualnosci/premier-mateusz-morawiecki-o-korzysciach-programu-dobry-start.html (dostęp: 1.05.2020).

67 P. Miączyński, L. Kostrzewski, Jarosław Kaczyński poparł zakaz handlu w niedzielę, https://wyborcza.biz/biznes/1,147743,20330173,kaczynski-poparl-zakaz-handlu-w-niedziele.html (dostęp: 01.05.2020).

${ }^{68}$ Episkopat wspiera obywatelski projekt ustawy ograniczajacej handel w niedziele, https:// www.gazetaprawna.pl/artykuly/1026900,episkopat-wspiera-obywatelski-projekt-ustawy-ograniczajacej-handel-w-niedziele.html (dostęp: 1.05.2020).

69 Rzad zaakceptowat projekt zakazu handlu w niedzielę. Ograniczenie nie obejmie... dewocjonaliów, https://wiadomosci.gazeta.pl/wiadomosci/7,114871,21531078,rzad-zaakceptowal-projekt-zakazu-handlu-w-niedziele-ograniczenie.html (dostęp: 1.05.2020).

70 Ł. Lipiński, Jak głosowali młodzi i starsi, miasto $i$ wieś, https://www.polityka.pl/tygodnikpolityka/kraj/1928140,1,jak-glosowali-mlodzi-i-starsi-miasto-i-wies.read (dostęp: 1.05.2020). 
dzie trzynastka na stałe, waloryzacja kwotowo-procentowa, będziemy się starali polepszać byt najbiedniejszych emerytów, podnosić ich minimalną emeryturę"71.

Skupienie akurat na polityce rodzinnej wpisuje się w regionalną specyfikę. Politolog Iwan Krastev oraz prawnik Stephen Holmes w swojej książce poświęconej kryzysowi liberalizmu wskazują, że jedną z przyczyn tak zwanej nieliberalnej demokracji w Europie Środkowej jest masowa emigracja w tym rejonie po przystąpieniu do Unii Europejskiej ${ }^{72}$ — stąd populistyczną politykę socjalną można postrzegać jako reakcję na kryzys demograficzny, wynikający z emigracji oraz spadku dzietności społeczeństw regionu. Rządy populistyczne, przynajmniej w Europie Środkowo-Wschodniej, okazują się o wiele bardziej zdolne odpowiedzieć wprost na te wyzwania niż rządy liberalne.

Przytoczone przykłady wskazują, że populizm u władzy wprowadza, w porównaniu do wcześniejszych, dość rozbudowaną politykę socjalną — przy czym transfery socjalne powiązane są z dyskursem godnościowym. W przypadku Polski jest to także połączone $\mathrm{z}$ dyskursem dowartościowania rodziny, który jest wywiedziony ze społecznej doktryny Kościoła katolickiego. Sama taka polityka, niezależnie od jej ideologicznej podstawy, jest zgodna z koncepcją socjalnych praw człowieka, w szczególności z art. 25 (prawo do odpowiedniego poziomu życia) oraz art. 26 (prawo do nauki) Powszechnej deklaracji praw człowieka. Co więcej, prawa socjalne można postrzegać jako jeden z warunków operacjonalizacji innych praw. Dopiero mając minimalny poziom zabezpieczenia socjalnego, można domagać się respektowania pozostałych praw. Pod tym względem populizm u władzy można postrzegać jako zwiększenie ochrony wynikającej z tym praw.

Zgodnie z danymi Głównego Urzędu Statystycznego w 2016 roku zaobserwowano spadek zasięgu ubóstwa skrajnego wśród dzieci w wieku 0-17 lat (z 9\% w 2015 roku do nieco mniej niż 6\% w 2016 roku $^{73}$ ). GUS wskazuje także na ogólną poprawę sytuacji materialnej gospodarstw domowych w Polsce. Ubóstwo gospodarstw domowych spadło z 6,5\% osób w 2015 roku do 4,9\% osób w 2016 roku. Jednakże w 2018 roku wskaźnik ten wzrósł do 5,4\% ${ }^{74}$. Komentatorzy ekonomiczni wskazują, że wynika to z pośpiechu, braku strategicznej wizji oraz jasnych celów programów socjalnych ${ }^{75}$. Wydaje się, że wynika to także z faktu, że polityki

71 M. Kośka, 13. emerytura. Jarosław Kaczyński zdradzit, czy będzie wypłacana w kolejnych latach, https://www.money.pl/emerytury/13-emerytura-jaroslaw-kaczynski-zdradzil-czy-bedzie-wyplacana-w-kolejnych-latach-6421691893560961a.html (dostęp: 1.05.2020).

72 I. Krastev, S. Holmes, The Light that Failed, London 2020, s. 27-33.

73 GUS, Ubóstwo w Polsce w latach 2015-2016, Warszawa 2017, s. 6.

74 GUS, Zasięg ubóstwa ekonomicznego w 2018, Warszawa 2019.

75 I. Magda et al., ,Rodzina 500+”- ocena programu i propozycje zmian, Fundacja Instytut Badań Strukturalnych 2019, https://ibs.org.pl/publications/rodzina-500-ocena-programu-i-propozycje-zmian/ (dostęp: 1.05.2020); A. Gromada, Rodzina 500+ jako polityka publiczna, Instytut Studiów Zawansowanych 2017, https://krytykapolityczna.pl/file/sites/4/2017/09/Gromada_Rodzina-500.pdf (dostęp: 1.05.2020). 
socjalne populistów są nie tylko traktowane w kategoriach ekonomicznych, lecz także ideologicznych. Idzie o stworzenie normatywnej wizji rodziny jako podstawy społeczeństwa. Konieczność utrwalenia własnej wizji wspólnoty ma takie samo znaczenie, jak realne efekty tych programów. W celu utrzymania spójności ideologicznej populiści wydają się akceptować ograniczoną efektywność swoich polityk socjalnych. Definiując swoje programy socjalne w kategoriach moralnych (,godność”), populizm ogranicza swoją możliwość do rewizji tych programów.

\section{Nowa polityka praw}

Relacja między populizmem a prawami człowieka nie jest jednoznaczna i nie daje się sprowadzić do prostej tezy o niekompatybilności. Z jednej strony rządy populistyczne ograniczają prawa człowieka — mniejszości seksualnych, kobiet oraz imigrantów. Jedynie w ograniczonym zakresie czynią to przez bezpośrednią legislację. Częściej czynią to pośrednio przez marginalizację i stygmatyzację określonych grup w przestrzeni publicznej, reinterpretację istniejących praw oraz ograniczanie dostępu do praw przez przeszkody biurokratyczne. Działania takie mają charakter rozproszony. Z drugiej strony, populizm u władzy wzmacnia socjalne prawa człowieka przez prowadzenie dość rozbudowanej polityki socjalnych. Z jej programów mogą korzystać wszyscy obywatele; kryteria dostępu do nich nie mają charakteru jawnie ideologicznego.

Jak więc wytłumaczyć tę dialektykę ograniczania-wzmacniania praw przez populizm? Wydaje się, że populizm nie jest prostym zaprzeczeniem praw człowieka, lecz próbą wprowadzenia ich nowej polityki. Liberalna polityka praw człowieka oparta jest na dystrybucji jednostkowej. Przyrównując prawa do towarów, możemy powiedzieć, że w dyskursie liberalnym są one dystrybuowane równo - na poziomie symbolicznym — między jednostkami. Podmiotem dystrybuującym są także jednostki, a mówiąc ściślej — państwo jako agregat jednostek. Jednostka i jej przyrodzona godność są źródłem i adresatem praw. Populizm zrywa z taką ekonomią. Podmiotem dystrybuującym staje się metafizyczna i jednoznacznie pozytywna moralnie wspólnota — naród. Ucieleśnieniem tej wspólnoty jest organizacja polityczna — państwo, które reprezentowane jest przez polityków. Prawa zaś są dystrybuowane nie między jednostkami, lecz elementami budującymi tę wspólnotę (głównie rodzinę).

Zmiana przyjętej ekonomii prawa ma przy tym charakter performatywny ${ }^{76}$. Wykluczenie na poziomie dostępu do sfery publicznej jest umacniane poprzez transfery socjalne. Ujęcie takie może scementować nową wizję wspólnoty. Innymi słowy im dłużej populizm pozostaje u władzy i jest w stanie realizować nową politykę praw, tym bardziej wytwarza wspólnotę, która odpowiada jego wizji. Takie ujęcie pozwala

76 J. Butler, Walczące słowa. Mowa nienawiści i polityka performatywna, przeł. A. Ostolski, Warszawa 2010. 
postawić pytanie o strategię oporu przeciwko ograniczeniu dostępu do przestrzeni publicznej grupom marginalizowanym. Strategia taka powinna uwzględniać nową, wykluczająco-włączającą politykę praw człowieka. Samo skupianie się na wykluczającym aspekcie polityki populistycznej może nie być wystarczające. Strategia oporu powinna uznać element inkluzyjności populizmu i doprowadzić go do logicznej konkluzji, także w stosunku do przestrzeni publicznej. Taki opór wymaga wypracowania nowej wizji wspólnoty politycznej, która połączy wolność osobistą jednostki z socjalnymi prawami kolektywnymi. Skoro populizm mieści się w zakresie demokracji, to wymaga demokratycznych, a więc politycznych odpowiedzi. Tworzenie takich wizji jest zadaniem polityki praw człowieka.

\section{Bibliografia}

Balibar É., Co to jest polityka praw czlowieka?, przeł. J. Kochan, http://www.nowakrytyka.pl/pl/ artykuly/Nk_on-line/?id=583.

Benhabib S., Prawa innych. Przybysze, rezydenci i obywatele, przeł. M. Filipczuk, Warszawa 2015.

Butler J., Walczace stowa. Mowa nienawiści i polityka performatywna, przeł. A. Ostolski, Warszawa 2010.

Canovan M., Polityka dla ludzi. Populizm jako ideologia dla demokracji, [w:] Demokracja w obliсzи populizmu, red. Y. Meny, Y. Surel, Warszawa 2007.

Canovan M., Populizm, [w:] Populizm, red. O. Wysocka, Warszawa 2010.

Douzinas C., Human Rights and the Empire, Oxford-New York 2017.

Duda M., Dogmat płci. Polska wojna z gender, Gdańsk 2016.

Fukuyama F., Koniec historii i ostatni człowiek, przeł. T. Bieroń, Kraków 2017.

Kocemba K., Kontrpubliczności polskiego konstytucjonalizmu na przyktadzie praw kobiet, „Krytyka Prawa" 11, 2019, nr 1.

Krastev I., Holmes S., The Light that Failed, London 2020.

Krastev I., The Populist Moment, https://www.eurozine.com/the-populist-moment/.

Macrae C.N., Stangor Ch., Hewstone M., Stereotypy i uprzedzenia, przeł. M. Majchrzak, A. i M. Kacmajor, A. Nowak, Gdańsk 1999.

Moyn S., The Last Utopia: Human Rights in History, Harvard 2012.

Müller J.-W., Co to jest populizm?, przeł. M. Sutowski, Warszawa 2017.

Pelinka A., Populizm w Europie - w poszukiwaniu znaczenia mglistego pojęcia, [w:] Populizm w Europie. Defekt i przejaw demokracji?, red. J.M. De Waele, A. Pacześniak, Warszawa 2010.

Singer B.J., Pragmatism, Rights and Democracy, New York 1999.

Waldron J., The rule of law and the importance of procedure, [w:] Getting to the Rule of Law, red. J.E. Fleming, New York 2011.

\section{Akty prawne, orzeczenia}

Europejska konwencja o ochronie praw człowieka i podstawowych wolności, https://www.gov.pl/ web/rodzina/europejska-konwencja-o-ochronie-praw-czlowieka-i-podstawowych-wolnosci.

Konstytucja Rzeczypospolitej Polskiej z dnia 2 kwietnia 1997 roku, Dz.U. z 1997 r. Nr 78, poz. 483. Orzeczenie Trybunału Konstytucyjnego z dnia 28 maja 1997 roku, sygn. akt. K 26/96.

Ustawa z dnia 20 maja 1971 roku — Kodeks wykroczeń, tekst jedn. Dz.U. z 2019 r. poz. 821.

Ustawa z dnia 26 czerwca 1974 roku - Kodeks pracy, Dz.U z 1974 r. Nr 24, poz. 141.

Ustawa z dnia 6 czerwca 1997 roku - Kodeks karny, Dz.U. z 1997 r. Nr 88, poz. 553.

Wyrok Sądu Najwyższego z dnia 14 czerwca 2018 roku, sygn. akt. II KK 333/18.

Studenckie Prace Prawnicze, Administratywistyczne

i Ekonomiczne 31, 2020

(C) for this edition by CNS 
Wyrok Sądu Okręgowego w Łodzi z dnia 26 maja 2017 roku, sygn. akt. V Ka 557/17.

Wyrok Sądu Rejonowego dla Łodzi-Widzewa w Łodzi z dnia 31 marca 2017 roku, sygn. akt VII W 1640/16.

Wyrok Trybunału Konstytucyjnego z dnia 26 czerwca 2019 roku, sygn. akt K 16/17.

\section{Raporty, statystyki}

Bilewicz M., Bulska D., Hansen K., Soral W., Świderska A., Winiewski M., Mowa nienawiści, mowa pogardy w Polsce 2016, http://www.batory.org.pl/upload/files/pdf/MOWA_NIENAWISCI_MOWA_POGARDY_INTERNET.pdf.

Federacja na rzecz Kobiet i Planowania Rodziny, Dane o legalnej aborcji w 2017 roku, https:// federa.org.pl/dane2017/.

Federacja na Rzecz Kobiet i Planowania Rodziny, Prawa reprodukcyjne kobiet. Wybrane ustugi zdrowia reprodukcyjnego w krajach Unii Europejskiej, https://rownosc.info/media/uploads/zdrowie reprodukcyjne_ue.pdf.

GUS, Ubóstwo w Polsce w latach 2015-2016, Warszawa 2017.

GUS, Zasięg ubóstwa ekonomicznego w 2018, Warszawa 2019.

ILGA Europe, Rainbow Europe 2013, https://www.ilga-europe.org/rainboweurope/2013.

Państwowa Komisja Wyborcza, https://wybory2018.pkw.gov.pl/pl/dane-w-arkuszach.

\section{Źródła internetowe}

Chrzczonowicz M., Nastolatki opychają się pigułkami dzień po. Są badania, które dementuja bzdurę Radziwitta, https://oko.press/nastolatki-opychaja-sie-pigulkami-dzien-sa-badania-ktore-dementuja-bzdure-radziwilla/.

Ciastoch M., 30 proc. Polski to strefy ,,wolne od LGBT'. Ta mapa pokazuje, gdzie zezwala się na nienawiść, https://noizz.pl/lgbt/mapa-nienawisci-wobec-lgbt-30-proc-polski-to-strefy-wolne-od-lgbt-atlas-nienawisci/r3erj5p.

Episkopat wspiera obywatelski projekt ustawy ograniczajacej handel w niedziele, https://www. gazetaprawna.pl/artykuly/1026900, episkopat-wspiera-obywatelski-projekt-ustawy-ograniczajacej-handel-w-niedziele.html.

Flis D., PiS złamat obietnice wyborcza. Odrzucajac projekt „Ratujmy Kobiety, https://oko.press/ pis-zlamal-obietnice-wyborcza-odrzucajac-projekt-ratujmy-kobiety/.

„, Gazeta Polska” z nalepka ,, Strefa wolna od LGBT". Rabiej zgłosi to do prokuratury, Sakiewicz zarzuca mu cenzure, https://www.wirtualnemedia.pl/artykul/gazeta-polska-strefa-wolna-od-lgbt-naklejka-pawel-rabiej-zglosi-to-do-prokuratury-tomasz-sakiewicz-zarzuca-mu-cenzure\#.

Gromada A., Rodzina 500+ jako polityka publiczna, Instytut Studiów Zawansowanych 2017, https:// krytykapolityczna.pl/file/sites/4/2017/09/Gromada_Rodzina-500.pdf.

J. Kaczyński o imigrantach: Mamy pełne moralne prawo powiedzieć „nie”, https://niezalezna. p1/101460-j-kaczynski-o-imigrantach-mamy-pelne-moralne-prawo-powiedziec-nie.

JarosławKaczyński: Waraodnaszychdzieci, https://www.rp.p1/Prawo-i-Sprawiedliwosc/190319420-Jaroslaw-Kaczynski-Wara-od-naszych-dzieci.html.

Kaczyński: homoseksualiści kwestionujący rodzinę zagrożeniem dla cywilizacji, https:/queer.pl/ news/203956/kaczynski-homoseksualisci-kwestionujacy-rodzine-zagrozeniem-dla-cywilizacji.

Kaczyński: naszym wielkim celem jest przywrócenie godności Polaków!, https://telewizjarepublika. pl/kaczynski-naszym-wielkim-celem-jest-przywrocenie-godnosci-polakow,77247.html.

Kaczyński: Będziemy dążyli do tego, aby aborcji było dużo mniej niż obecnie, https://www.mp.pl/ pacjent/ciaza/aktualnosci/151453,kaczynski-bedziemy-dazyli-do-tego-aby-aborcji-bylo-duzo-mniej-niz-obecnie.

Studenckie Prace Prawnicze, Administratywistyczne

i Ekonomiczne 31, 2020

(C) for this edition by CNS 
Kośka M., 13. emerytura. Jarosław Kaczyński zdradził, czy będzie wypłacana w kolejnych latach, https://www.money.pl/emerytury/13-emerytura-jaroslaw-kaczynski-zdradzil-czy-bedzie-wyplacana-w-kolejnych-latach-6421691893560961a.html.

Kraus M., Radziwitt powiedziat, że nie przepisałby pigułki ,,dzień po” nawet pacjentce zgwałconej. „Taka odmowa jest bezprawna”, https://www.wysokieobcasy.pl/wysokie-obcasy/7,115167,214 10876,radziwill-powiedzial-ze-nie-przepisalby-pigulki-dzien-po-nawet.html.

Kubicka-Żach K., Uchwaty anty-LGBT przyjmowane raczej „,na wyrost”, https://www.prawo.pl/ samorzad/uchwaly-anty-lgbt-powody-ich-przyjmowania-przez-rady,456469.html.

Lipiński Ł., Jak głosowali młodzi i starsi, miasto $i$ wieś, https://www.polityka.pl/tygodnikpolityka/ kraj/1928140,1,jak-glosowali-mlodzi-i-starsi-miasto-i-wies.read.

Magda I., Brzeziński M., Chłon-Domińczak A., Kotowska I. E., Myck M., Najsztub M., Tyrowicz J., „Rodzina 500+" - ocena programu i propozycje zmian, Fundacja Instytut Badań Strukturalnych 2019, https://ibs.org.pl/publications/rodzina-500-ocena-programu-i-propozycje-zmian/.

Miączyński P., Kostrzewski L., Jarosław Kaczyński poparł zakaz handlu w niedzielę, https://wyborcza.biz/biznes/1,147743,20330173,kaczynski-poparl-zakaz-handlu-w-niedziele.html.

Pacewicz P., ,, Tu chodzi o zwykte, codzienne bezpieczeństwo Polaków”. Kaczyński mówi o „,uchodźcach”, ale narusza bezpieczeństwo ,obcych”, którzy już w Polsce sa, https://oko.press/chodzi-o-zwykle-codzienne-bezpieczenstwo-polakow-kaczynski-mowi-o-uchodzcach-narusza-bezpieczenstwo-obcych-ktorzy-juz-polsce-sa/.

Premier Mateusz Morawiecki o korzyściach programu „Dobry Start”, https://www.premier.gov.pl/ wydarzenia/aktualnosci/premier-mateusz-morawiecki-o-korzysciach-programu-dobry-start.html.

Radio Maryja, Min. B. Borys-Szopa: rodzina jest naszym priorytetem i najlepsza inwestycja, https:// www.radiomaryja.pl/informacje/min-b-borys-szopa-rodzina-jest-naszym-priorytetem-i-najlepsza-inwestycja/.

Rumieńczyk B., Temat, który rozpalił nas do czerwoności. I o którym zapomnieliśmy, https://wiadomosci.onet.pl/tylko-w-onecie/polityka-pis-wobec-imigrantow/e1xnpq0.

Rodzina 500 plus, https://www.gov.pl/web/rodzina/rodzina-500-plus.

Rząd zaakceptowat projekt zakazu handlu w niedzielę. Ograniczenie nie obejmie... dewocjonaliów, https://wiadomosci.gazeta.pl/wiadomosci/7,114871,21531078,rzad-zaakceptowal-projekt-zakazu-handlu-w-niedziele-ograniczenie.html.

Zbigniew Ziobro: aborcja niezgodna z Konstytucja, https://www.rp.pl/Zdrowie/305299968-Zbigniew-Ziobro-aborcja-niezgodna-z-Konstytucja.html.

Szydło: 500 złotych na drugie dziecko będzie moim pierwszym projektem, http://web.archive.org/ web/20150904142630/https:/www.tvn24.pl/wiadomosci-z-kraju,3/500-zlotych-na-drugie-dziecko-pierwszym-projektem-beaty-szydlo,573711.html.

Prezes PiS: „Nie będzie w Polsce matżeństw homoseksualnych, nie będzie adopcji dzieci”. Plan Rabieja? ,Nie, nigdy nie”, https://wpolityce.pl/polityka/463846-prezes-pis-trwa-atak-na-dzieci-my-sie-na-to-nie-zgadzamy.

Zandberg: Świadczenia społeczne, jak 500+, powinny być indeksowane, https://www.gazetaprawna. pl/artykuly/1207851,zandberg-swiadczenia-spoleczne-500-plus-powinny-byc-indeksowane.html.

Studenckie Prace Prawnicze, Administratywistyczne

i Ekonomiczne 31, 2020

(C) for this edition by CNS 